\title{
Seismic Analysis of AP1000 Nuclear Island Structure by Using the Finite Element Software ANSYS
}

\author{
Nguyen Dinh Kien, Vu Lam Dong
}

\begin{abstract}
Seismic analysis of AP1000 nuclear island structure by using the commercial finite element software ANSYS is presented. Using the ANSYS Workbench, a sophisticated threedimensional finite element model of the structure is created and employed in the analysis. Dynamic response of the structure to both the one-directional and three-directional acceleration time histories are considered in the analysis. The time histories for the relative displacement, velocity and absolute acceleration of the structure are obtained for various earthquakes, including American El Centro, Japanese Kobe and Vietnamese Dien Bien earthquakes. The numerical results show that the dynamic characteristics obtained by using one-directional and thee-directional acceleration time histories are different, and the three three-directional acceleration time histories should be employed in the seismic analysis. The result also reveals that the nuclear island is safer in Dien Bien earthquake that it is in El Centro and Kobe earthquakes. The distribution of the von Mises stresses of the structure according to the maximum displacement at the top point is also examined and highlighted.
\end{abstract}

Index Terms - AP1000, nuclear island, seismic analysis, finite element model, dynamic response, ANSYS.

Manuscript Received on July 13th, 2016. Manuscript Revised December 06th, 2016.

The work presented in this article has been support by Vietnam Academy of Science and Technology, grant No. VAST01.06/16-17. The authors would like to thank Dr. Pham Ngoc Dong of Vinatom and Prof. Buntara Gan of Nihon University, Japan for their kindness to use ANSYS software.

Nguyen Dinh Kien is a research associate at Institute of Mechanics, Vietnam Academy of Science and Technology, 18 Hoang Quoc Viet, Hanoi, Vietnam (e-mail: ndkien@imech.vast.vn).

$\mathrm{Vu}$ Lam Dong is a researcher at Institute of Mechanics, Vietnam Academy of Science and Technology, 18 Hoang Quoc Viet, Hanoi, Vietnam (e-mail: vldong@imech.vast.vn).

\section{INTRODUCTION}

$T$ he AP1000, designed and developed by Westighouse Electric Company and its patners, is an advanced nuclear power plant with improved use of passive safety features. The plant has been chosen by China, and it is under consideration by Vietnamese government for Ninh Thuan 2 nuclear power plant.

The safety of a nuclear power plant under actions of natural disasters such as earthquakes and tsunamis is the most concerned of engineers and researchers in designing a new plant as well as in evaluating the existing plants. Various methods, including the numerical methods and facility survey, have been developled in assessing the behaviour of a nuclear plant under seismic loadings [1]. Among the numerical methods, the finite element method, is preferable due to its versatility in the spatial discretization. The seismic analysis of nuclear power structures by using the finite element method have been extensively reported in the literature. Manjuprasad et al. [2] derived a nonlinear isoparametric solid finite element for computing the dynamic response of reinforced concrete containment shell at nuclear plants subjected to seismic loading. The element with 20 nodes was developed by modelling the concrete in compression by elasto-viscoplastic constitutive laws and tensionstiffening effect by a strainsoftening rule. Various finite elements in ANSYS library, including the beam element, shell element and brick element have been employed by Tinic and Orr [3] to model different parts of the AP1000 plant in their dynamic analysis of the nuclear island structure. The stick and shell finite element models for seismic analysis of the AP1000 nuclear island structure have been developed by Tunon-Sanjur [4]. The effects of soil-structure interaction has 
been taken into consideration in the finite element models in Ref. [4]. Nakamura [5] presented a method in which the frequency-dependent soil impedance can be transformed to the time domain for evaluating the seismic behaviour of a nuclear power building deeply embedded into the soil. The finite element method was empoyed by the author in combination with the direct integration Newmark method to obtain the vibration characteristics of the nuclear building. A nonlinear three-dimensional finite element model for studying the ultimate seismic response and fragility assessment of a nuclear power building has been developed by Nakamura et al. in [6]. Also considering the fragility evaluation problem of nuclear power buildings, Perotti et al. [7] proposed a numerical procedure for investigating fragility of nuclear structures under action of seismic loading. The structures in the work have been considered to be isolated by a viscous damper system. The efffects of isolated system on the seismic behaviour of nuclear power structures are explored in more detail by several researchers. In this line of work, Hang et el. [8] developed the numerical models for seisemic behaviour of a sample isolated nuclear power building, and the authors showed that isolation systems greatly reduce both the median and dispersion of seismic demands on secondary systems in nuclear power plants. Zhao and Chen [9] utilized the finite element software ANSYS to carry out an investigation on the dynamic behaviour of isolated nuclear power buildings subjected to threedirectional seismic loading. The numerical results obtained from the finite element modelling are useful in evaluating the safety of the reinforced concrete contaiment under earthquakes. Chen et al. [10] also employed the ANSYS to compute the vibration modes and dynamic response of isolated and non-isolated AP1000 nuclear island building to earthquakes. The authors showed that the viscous damper system used to isolate the building has significant effect on the dynamic behaviour of building and the maximum accelerations of the isolated structure are considerably lower than that of the non-isolated one. Politopouos et al. [11] employed the finite elements and Lysmer radiation boundaries to model the soil domain under the nuclear power plant to investigate the effect of foundation embedment on the floor response spectra of an isolated nuclear power plant. The authors concluded that the base rocking excitation induced by soil-structure interaction may amplify the non-isolated modes' response. The finite element software ABAQUS was employed by Zhai et al. [12] to study the effect of aftershocks of earthquakes on the dynamic behaviour of nuclear buildings. The numerical results of the work indicate that the aftershocks have a significant effect on the responses of reinforced concrete containment in terms of maximum top accelerations, maximum top displacements and accumulated damage. The effects of fluid-structure interaction on the dynamic behaviour of nuclear power structures have been considered recently. Frano and Forasassi [13] presented the threedimensional sloshing analysis procedure which allows the fluid to follow the movement of the structure in their study of the effects of isolated system on the dynamic behaviour of nuclear reactors. With the help of the software ANSYS Zhao and Chen [14] examined the effect of fluidstructure interaction in their investigation on the free vibration of AP1000 shield building. The numerical result obtained in the work shows that the natural frequency increases by decreasing the water level in the tank. Also using the finite element modeling and taking the fluid-structure interaction into account, Zhao et al. [15] studied the effects of various elevations and shapes of air intake in water tank on the dynamic response of AP1000 shield building to seismic loading. The authors showed that the von Mises stress of both rectangular and circular air intakes at the lower location were greater than that of the higher location and the stress for circular air intake was less than that of rectangular air intake under seismic loading. Also consideration of fluidstructure interaction, $\mathrm{Xu}$ et al. [16] presented a vibration analysis of AP1000 shield building by modeling the building by 8-node solid elements. The results indicate that the high water level in the water tank can limit the vibration of the AP1000 shield building and can more efficiently dissipate the kinetic energy of the AP1000 shield building by the fluid-structure interaction.

The AP1000 nuclear power plant, as above mentioned, is considered by Vietnamese government for Ninh Thuan 2 nuclear power plant, and thus understanding seismic behaviour of structures at the plant is important from both the design of the plant and research points of view. Among the five main buildings of the AP1000, the safety of the nuclear island building under earthquakes is the most important, and it should be 
investigated. In this paper, the seimic analysis of the AP1000 nuclear island structure by using the finite element software ANSYS is presented. With the help of the ANSYS Workbench, a threedimensional finite element model is created and employed in the analysis. The dynamic characterictics, including the time histories for displacements, velocities, accelerations and the distribution of equivalent von Mises stress of the structure are obtainde for various earthquakes, including El Centro 1944, Kobe 1995 and Dien Bien 2001 earthquakes. The dynamic behaviour of the structure in the earthquakes is discussed in consequency.

\section{ANSYS WORKBENCH AND Finite ELEMENT MODEL FOR NUCLEAR ISLAND STRUCTURE}

ANSYS [17] is a finite element package with a library of large number of elements. With a strong solver, ANSYS allows to analyze complex problems in the field of structural mechanics. With Workbench platform enables ANSYS to be user friendly and easier to create a finite element model. The ANSYS Workbench is employed in the present paper to develop the finite element model for seismic analysis.

The AP1000 nuclear island consists of the containment building with the steel containment vessel and the containment internal structures, the shield building, and the auxiliary building as depicted in Fig. 1. The nuclear island with length of $77.42 \mathrm{~m}$, width of $26.67 \mathrm{~m}$, height of 81.98 , radius of shield building is $22.1 \mathrm{~m}$, radius of containment vessel is $19.8 \mathrm{~m}$ and wall thickness of $0.92 \mathrm{~m}$ is formed from steel and reinforced concrete. The containment vessel is made of pure steel with thickness of $0.041 \mathrm{~m}$. Using ANSYS Workbench, a sophisticated three-dimensional finite element model for the nuclear island structure as shown in Fig. 2 can easily created. The model consists of shell and brick elements in which the shell elements are employed to model the steel containment vessel and shield building, whereas the brick elements are used to model the remaining parts of the structures.

The interface between the upper parts of the structure and the basemat as well as between the walls of the building and the upper basemat are modeled by the share node option of ANSYS. In order to ensure appropriate of the chosen mesh, convergence of the mesh has been carried out for finding an acceptable mesh. As a result, a mesh with a total number of 88349 elements, in which 2192 elements are share node elements, is decided to employ in the analysis.

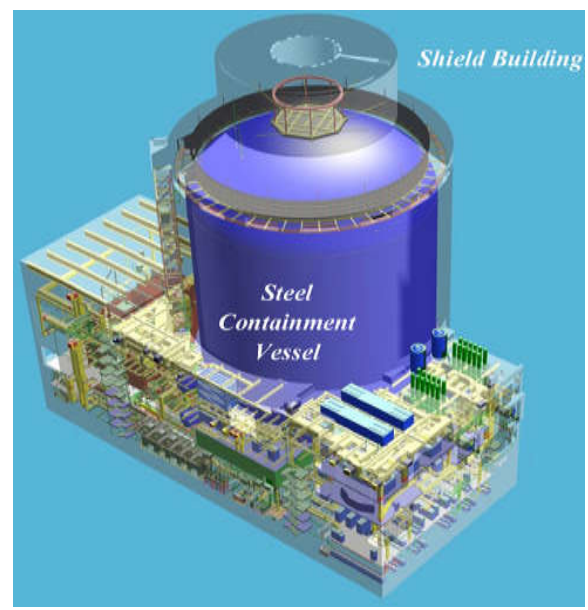

Figure 1. Main components of AP1000 nuclear island structure [4].
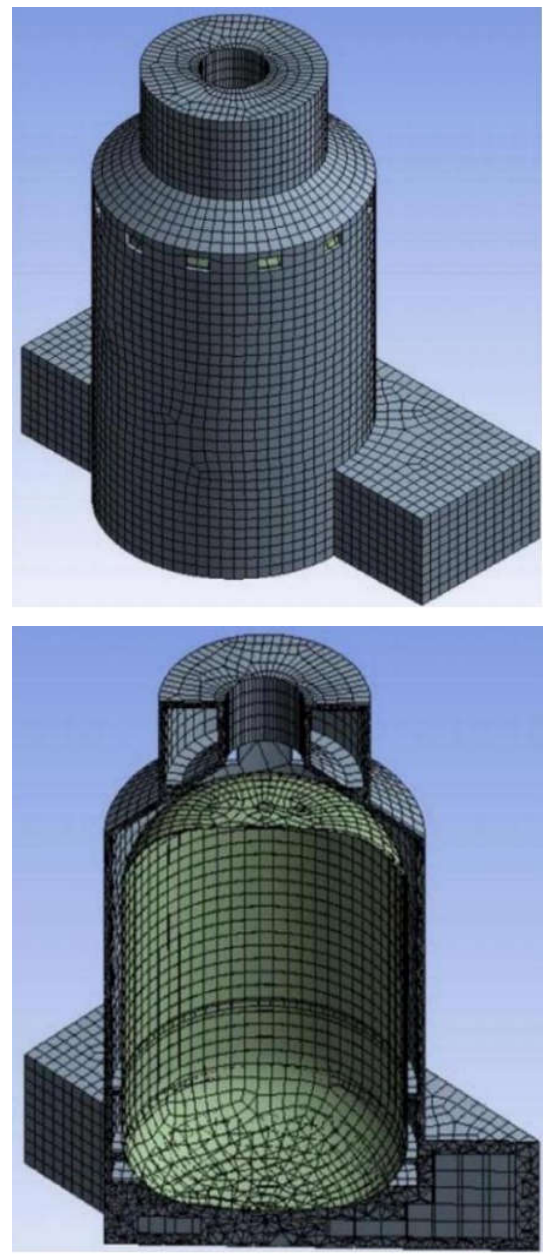

Figure 2. Finite element model for AP1000 nuclear island structure. 
3 Finite ElEMENT SEISMiC ANALysis

Following the standard procedure of finite element analysis, the stiffness and mass matrices for the structure are formed, and the equations of motion for seismic analysis can be written in the following form [18]

$\mathbf{M} \ddot{\mathbf{D}}+\mathbf{C} \dot{\mathbf{D}}+\mathbf{K D}=-\mathbf{M} \ddot{\mathbf{D}}_{g}$

where $\mathbf{M}, \mathbf{C}, \mathbf{K}$ are, respectively, the mass, damping and stiffness matrices of the structure; $\mathbf{D}$ is the vector of unknown relative nodal displacements, $\quad \dot{\mathbf{D}}=\partial \mathbf{D} / \partial t, \ddot{\mathbf{D}}=\partial^{2} \mathbf{D} / \partial t^{2}$ are the relative nodal velocities and nodal. The right hand-side of (1) defines the inertia forces due to the ground motion, in which $\ddot{\mathbf{D}}_{g}$ is the vector of ground motion, defined as

$$
\ddot{\mathbf{D}}_{g}(t)=\ddot{\mathbf{D}}_{a}-\ddot{\mathbf{D}}
$$

with $\ddot{\mathbf{D}}_{a}$ is the vector of absolute nodal accelerations.

In (1), $\mathbf{I}$ is the influence coefficient vector, having 1 for elements corresponding to degrees of freedom in the direction of the applied ground motion and zero for the other degrees of freedom. For the onedirectional ground motions the vector $\mathbf{I}$ is of the [18]

$$
\mathbf{I}=\left[\begin{array}{lllllll}
1 & 0 & 0 & 1 & 0 & 0 & -------
\end{array}\right]
$$

and for three-directional ground motions, the vector I has the following form

$$
\mathbf{I}=\left[\begin{array}{lllllll}
1 & 0 & 0 & 1 & 0 & 0 & -------- \\
0 & 1 & 0 & 0 & 1 & 0 & ------- \\
0 & 0 & 1 & 0 & 0 & 1 & -------
\end{array}\right]
$$

The damping effect must be considered in the seismic analysis of the structure, and the proportional damping is adopted herein. In this regard, the damping matrix $\mathbf{C}$ in Eq. (1) is formed by linear combination of the structural stiffness matrix $\mathbf{K}$ and the mass matrix $\mathbf{M}$ as

$$
\mathbf{C}=\alpha \mathbf{K}+\beta \mathbf{M}
$$

where $\alpha$ and $\beta$ are, the stiffness and mass proportional damping coefficients, respectively. The damping coefficients can be calculated from the critical damping ratio and the structural natural frequencies as follows

$$
\alpha=2 \xi \frac{\omega_{1} \omega_{2}}{\omega_{1}+\omega_{2}}, \beta=\frac{2 \xi}{\omega_{1}+\omega_{2}}
$$

where $\xi$ is the damping ratio, depending on the structural material, and a value $\xi=5 \%$ is assumed for both the concrete and steel of the structure herein; $\omega_{1}$ and $\omega_{2}$ are natural frequencies of the structure, which are necessary to choose to bound the design spectrum. Normally, $\omega_{1}$ is selected as the fundamental frequency, and a value of $30 \mathrm{~Hz}$ is chosen for the frequency $\omega_{2}$ because the spectral contents of seismic design are insignificant above this frequency [19].

In order to evaluate the dynamic response of the nuclear island building under earthquakes, the input Acceleration Time Histories (ATHs) of the earthquakes are applied at the base of the building. Fig. 3 shows the ATHs for North-South (N-S) component of Japanese 1995 Kobe and American 1940 El Centro earthquakes. The ATHs for the North-South (N-S), East-West (E-W) and UpDown (U-D) components of the Vietnamese 2001 Dien Bien earthquake is illustrated in Fig. 4. The ATHs in the figures are used to compute the nodal force vector in the right-hand side of (1) for evaluating the dynamic response by using the integration Newmark method. By examining Fig. 3 and Fig. 4 in more detail one can see that that the ground acceleration of Dien Bien earthquake is less than haft lower than that due to Kobe earthquake.

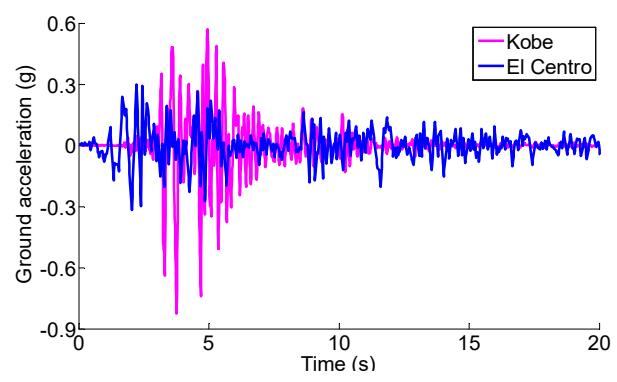

Figure 3. ATHs for N-S component of Kobe El Centro earthquakes. 


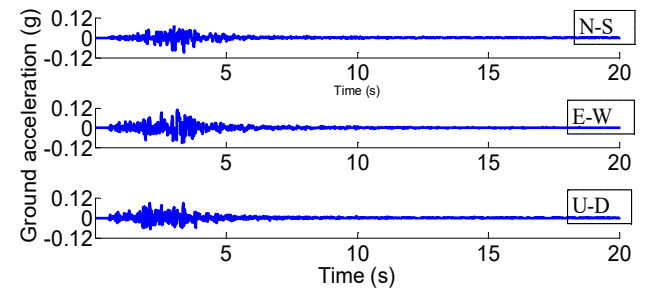

Figure 4. ATHs for three-directional components of Dien Bien earthquake.

\section{NumERICAL RESUlts AND DisCUSSION}

This section presents the numerical results on dynamic response of the nuclear island structure under several earthquakes. The structure is assumed to be fixed at its base. The results are given for both the one and three-directional ATHs. The difference between the dynamic characteristics obtained from the one-directional ATHs and three-directional ATHs is highlighted.

\subsection{Response to One-Directional ATHs}

Analysis of structures under seismic loading is complex and time consuming, especially for earthquakes with long ATHs. Due to the compute limitation and time saving, the seismic analysis of structures subjected to one-directional acceleration time histories of earthquakes is carried out. Here, the dynamic response of the nuclear island to the North-South ATHs of Kobe and El Centro earthquakes is examined.

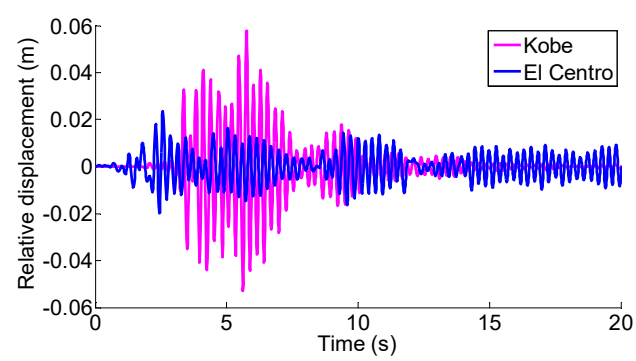

Figure 5. Time history for relative horizontal displacement at top point.

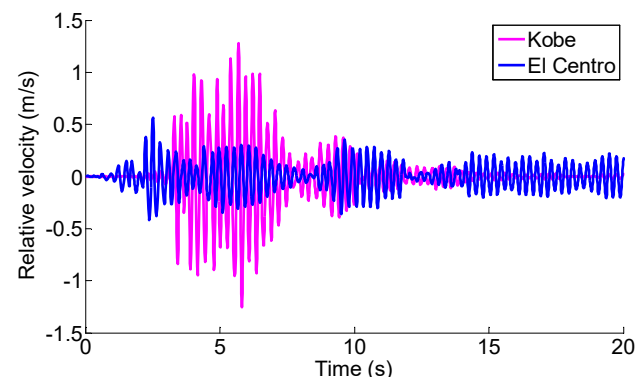

Figure 6. Time history for relative horizontal velocity at top point.

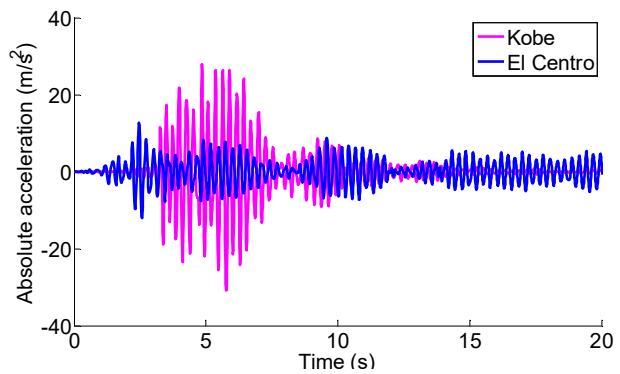

Figure 7. Time history for absolute horizontal acceleration at top point.

In Figs. 5-7, the time histories for the relative displacement, relative velocity and absolute acceleration at the top point of the nuclear island structure due to the N-S ATHs of Kobe and El Centro earthquakes are illustrated, respectively. The response of the structure to Kobe earthquake is considerably higher than that of the structure under El Centro earthquake. The maximum displacement, velocity and acceleration at the top point obtained from Kobe earthquake is more than twice higher than that obtained from El Centro earthquake. In addition, the response due to the Kobe earthquake is mainly contributed in the first 12 seconds, and it decays rapidly after this period. The displacement response under the El Centro earthquake is, however still relative large after the 12th second, and even until the 20th second, as seen from the figure. Similar remarks can be drawn for the response of the relative velocity and absolute acceleration at the top point as depicted in Fig. 6 and Fig. 7, respectively. In order to compare the response of the structure to the N-S ATHs of the two earthquakes in more detail, Table 1 lists the critical values of the dynamic characteristics of the structure obtained in Kobe and El Centro earthquakes. As clearly seen again from the Table, the maximum relative displacement, velocity and absolute acceleration at the top point of the structure obtained in Kobe earthquake are twice higher than that obtained in El Centro earthquake. 
TABLE 1

CRitical ResPonse VAlues of Dynamic Response at THE TOP POINT TO N-S ATHS OF KoBE AND El CENTRO

EARTHQUAKES

\begin{tabular}{ccc}
\hline \hline Response & $\begin{array}{c}\text { Kobe } \\
\text { Earthquake }\end{array}$ & $\begin{array}{c}\text { El Centro } \\
\text { Earthquake }\end{array}$ \\
\hline $\begin{array}{c}\text { Maximum } \\
\text { displacement }(\mathrm{m}) \\
\text { Minimum } \\
\text { displacement }(\mathrm{m})\end{array}$ & $5.7833 \times 10^{-2}$ & $2.3512 \times 10^{-2}$ \\
$\begin{array}{c}\text { Maximum velocity } \\
(\mathrm{m} / \mathrm{s})\end{array}$ & 1.2792 & $-1.9847 \times 10^{-2}$ \\
$\begin{array}{c}\text { Minimum velocity } \\
(\mathrm{m} / \mathrm{s})\end{array}$ & -1.2530 & -0.41577 \\
$\begin{array}{c}\text { Maximum } \\
\text { acceleration }\left(\mathrm{m} / \mathrm{s}^{2}\right)\end{array}$ & 27.9940 & 12.659 \\
$\begin{array}{c}\text { Minimum } \\
\text { acceleration }\left(\mathrm{m} / \mathrm{s}^{2}\right)\end{array}$ & -30.9320 & -11.999 \\
\hline \hline
\end{tabular}

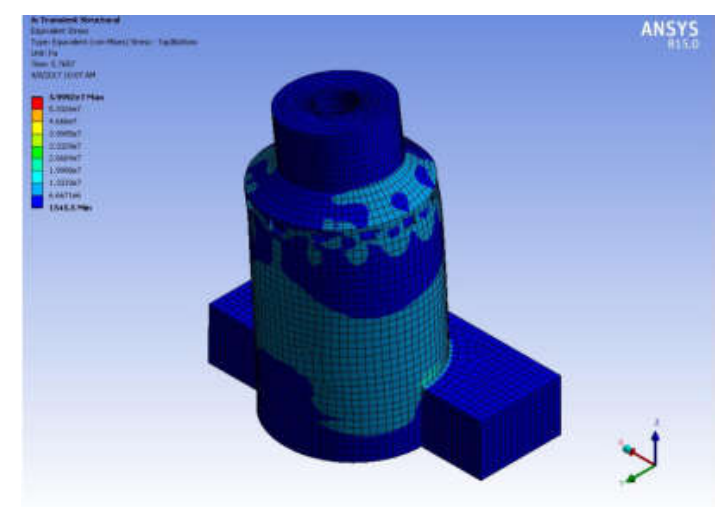

Figure 8. Distribution of equivalent von Mises of nuclear island under unidirectional ATH of Kobe earthquake.

The distributions of equivalent von Mises stress of the nuclear island at the time when the structure attained the maximum displacement at its top point is depicted in Fig. 8 and Fig. 9 for the Kobe and El Centro earthquakes, respectively. The von Mises stress $\left(\sigma_{\mathrm{vM}}\right)$ is defined as

$$
\sigma_{\mathrm{vM}}=\sqrt{\frac{1}{2}\left[\left(\sigma_{1}-\sigma_{2}\right)^{2}+\left(\sigma_{2}-\sigma_{3}\right)^{2}+\left(\sigma_{3}-\sigma_{1}\right)^{2}\right]}
$$

where $\sigma_{1}, \sigma_{2}$ and $\sigma_{3}$ are, respectively, the first, the second and the third principle stresses. The maximum stress, as seen from the figures, is occurred at the lower part of the nuclear island and for both the case of the earthquakes. The amplitude of the stress obtained from Kobe earthquake is somehow higher than that obtained from El Centro earthquake.

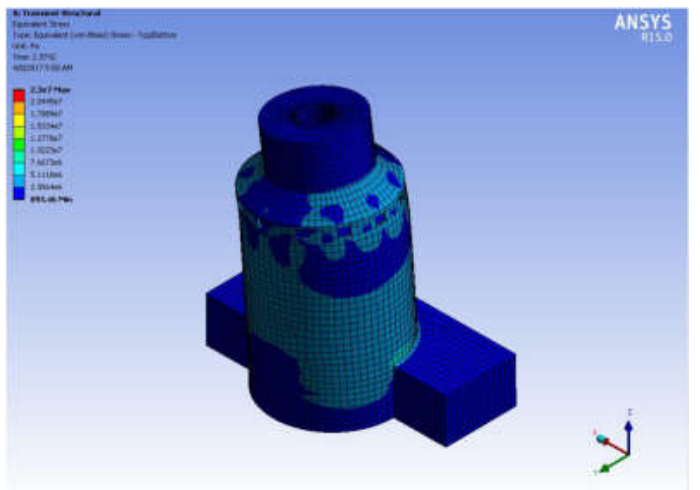

Figure 9. Distribution of equivalent von Mises distribution of nuclear island under unidirectional ATH of El Centro earthquake.

\subsection{Response to Three-Directional ATHs}

For more realistic, three-directional ATHs of earthquakes should be employed in seismic analysis of the nuclear island. In addition to the ATHs of Dien Bien earthquake in Fig. 4, the threedirectional components for ATH for El Centro earthquake which are available in Ref. [18] are employed herewith for computing the dynamic response of the structure.

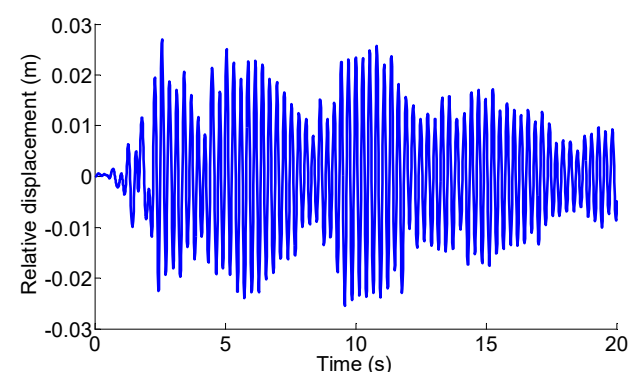

Figure 10. Time history for relative horizontal displacement at top point due to three-directional components of El Centro earthquake.

Figs. 10-12 illustrate the time histories for the relative displacement, relative velocity and absolute acceleration at the top point of the nuclear island due to the three-directional ATHs of El Centro earthquake, respectively. The corresponding figures obtained from the three-directional ATHs of Dien Bien earthquake are displayed in Figs. 13-15, respectively. The remarks which can be drawn can be made from these figures are as follows. 


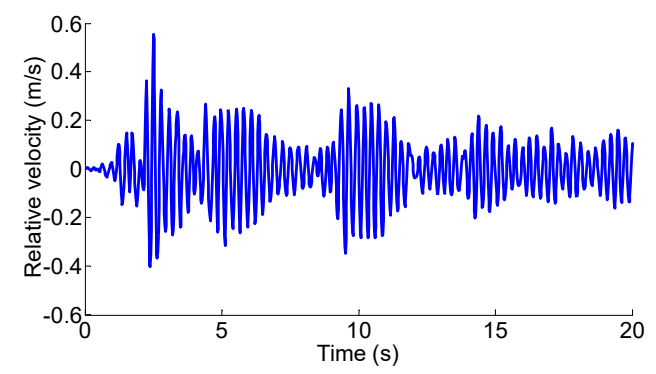

Figure 11. Time history for relative horizontal velocity at top point due to three-directional components of El Centro earthquake.

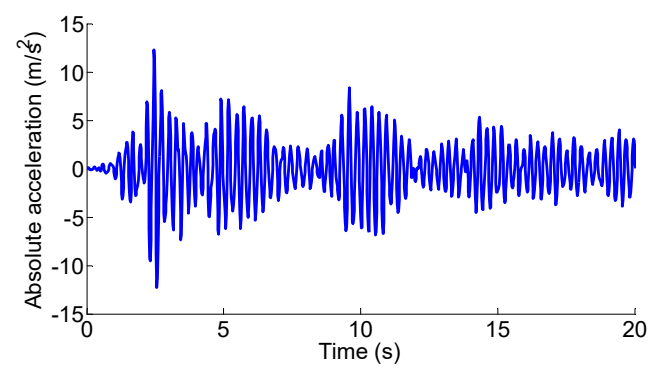

Figure 12. Time history for absolute horizontal displacement at top point due to three-directional components of El Centro earthquake.

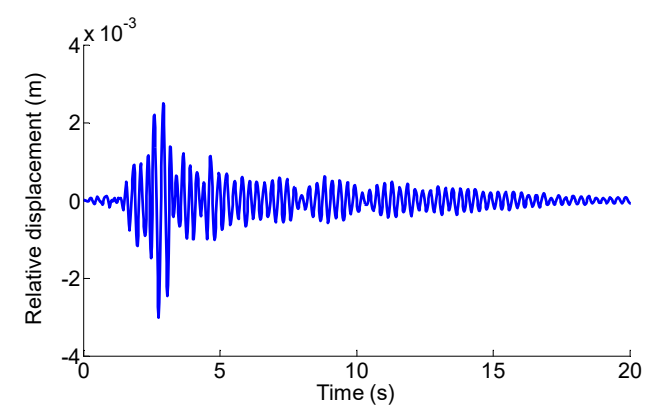

Figure 13. Time history for relative horizontal displacement at top point due to three-directional components of Dien Bien earthquake.

- The dynamic behavior of the nuclear island structure in Dien Bien earthquake is very much different from that in El Centro earthquake. In Dien Bien earthquake, the structure oscillates significantly during the first 5 seconds, and it then rapidly decays, but the situation is different when the structure is subjected to El Centro earthquake, and the structure still significantly oscillates after 10 seconds. In addition, the dynamic characteristics obtained by using the Dien Bien ATHs are much smaller than that obtained from the El Centro ATHs. This due to the fact that the acceleration of the Dien Bien ground acceleration, as seen from Figs. 3 and 4 is much smaller than that of the El Centro ground acceleration.

- The dynamic behavior obtained from the three-directional components of the El Centro ATHs is different from that using the onedirectional component of the ATHs. The relative displacement, velocity and absolute acceleration obtained from the three-directional components of ATHs are slightly higher than that obtained from the one-directional component. In other words, the dynamic characteristics are underestimated by using the one-directional ATHs, and threedirectional components of ATHs should be employed whenever possible.

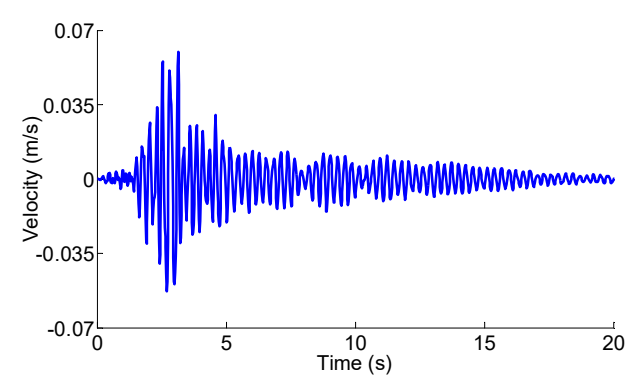

Figure 14. Time history for relative horizontal velocity at top point due to three-directional components of Dien Bien earthquake.

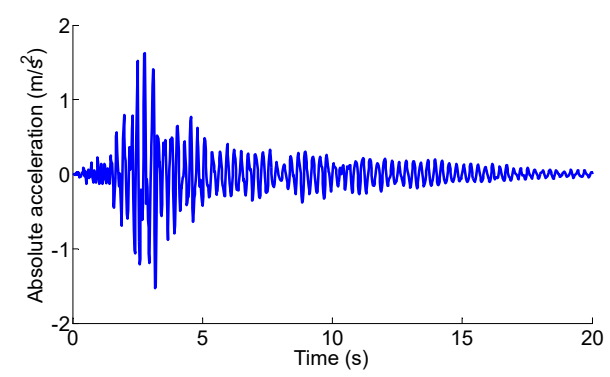

Figure 15. Time history for absolute horizontal acceleration at top point due to three-directional components of Dien Bien earthquake.

In order to show the difference between the dynamic response of the nuclear island obtained from the three-directional ATHs of Dien Bien and El Centro earthquakes, Table 2 lists the critical values of the relative displacement, relative velocity and absolute acceleration at the top point of the nuclear island structure. The response of the structure under El Centro earthquake, as clearly 
seen from the table, is almost ten times higher than that under Dien Bien earthquake. By comparing the data listed Table 1 and Table 2, one can see again that the critical values obtained from the three-directional component ATHs of the El Centro earthquake are lightly higher than that obtained by using the one-directional ATHs. From the obtained numerical results, one can conclude that the nuclear island is more safe in Dien Bien earthquake than in American El Centro earthquake.

TABLE 2

Critical Response Values of Dynamic Response at the Top PoINT DUE To 3-D ATHs DIEN BIEN AND El CENTRO EARTHQUAKES

\begin{tabular}{ccc}
\hline \hline Response & $\begin{array}{c}\text { Dien Bien } \\
\text { Earthquake }\end{array}$ & $\begin{array}{c}\text { El Centro } \\
\text { earthquake }\end{array}$ \\
\hline $\begin{array}{c}\text { Maximum } \\
\text { displacement }(\mathrm{m}) \\
\text { Minimum } \\
\text { displacement }(\mathrm{m})\end{array}$ & 0.0025 & $2.3512 \times 10^{-2}$ \\
$\begin{array}{c}\text { Maximum velocity } \\
(\mathrm{m} / \mathrm{s})\end{array}$ & -0.0030 & $-1.9847 \times 10^{-2}$ \\
$\begin{array}{c}\text { Minimum velocity } \\
(\mathrm{m} / \mathrm{s})\end{array}$ & -0.0530 & 0.56181 \\
$\begin{array}{c}\text { Maximum } \\
\text { acceleration }\left(\mathrm{m} / \mathrm{s}^{2}\right) \\
\begin{array}{c}\text { Minimum } \\
\text { acceleration }\left(\mathrm{m} / \mathrm{s}^{2}\right)\end{array}\end{array}$ & 1.6221 & -0.41577 \\
\hline \hline
\end{tabular}
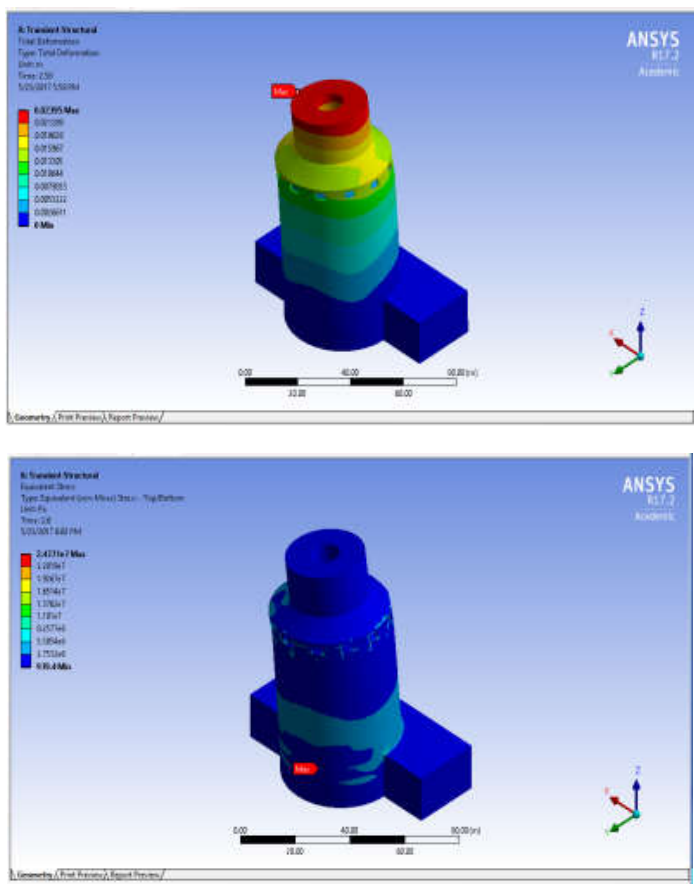

Figure 16. Deformed configuration (upper) and distribution of equivalent von Mises (lower) corresponding the maximun displacement at top point of of nuclear insland under El Centro earthquake.
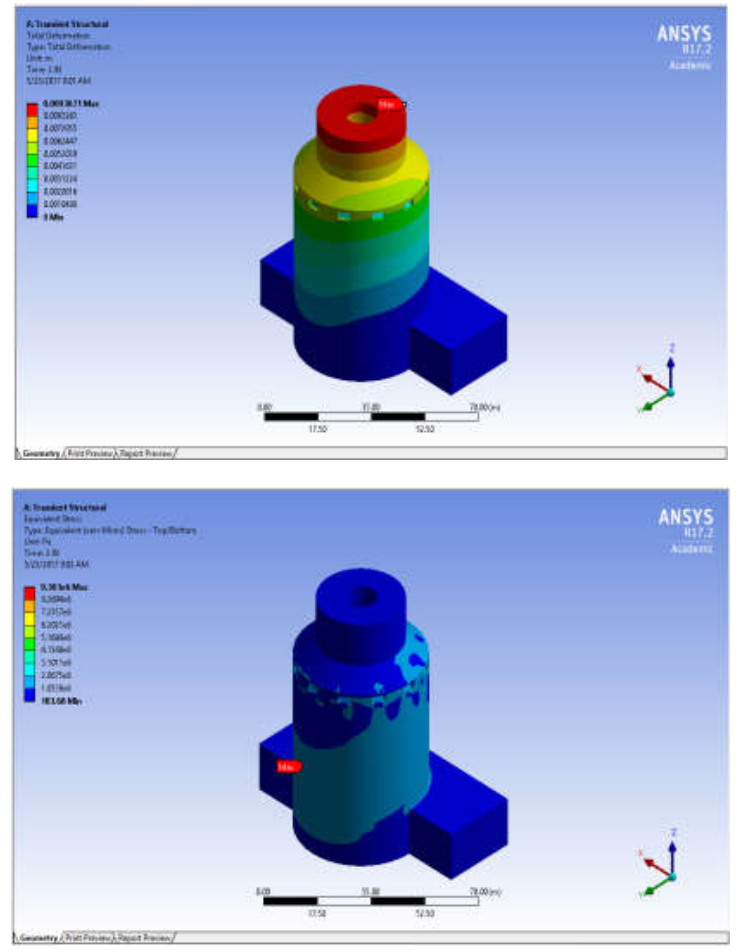

Figure 17. Deformed configuration (upper) and von Mises distribution (lower) corresponding the maximun displacement at top point of of nuclear insland under Dien Bien earthquake.

The deformed configurations and the distributions of equivalent von Mises stress according to the maximum displacements at the top point of the nuclear island structure under El Centro and Dien Bien eathquakes are depicted in Figs. 16 and 17, respectively. By examining these figures in more detail, one can see that the structure deforms more strongly under El Centro earthquake than it does under Dien Bien earthquake. The distribution of the von Mises stresses of the structure obtained from the two earthquakes is also different. In addition to the stress amplitude, the position where the stress reaches the maximum value is also differenet. In addition, the dynamic response of the structure due to the El Centro earthquake, and mentioned in the previous subsection, is not significant as that due to Kobe earthquahe, thus the nuclear island is more safe in the Dien Bien earthquake that it is in the El Centero and Kobe earthquakes. 


\section{CONCLUSION}

Seismic analysis of AP1000 nuclear island structure by using the finite element software ANSYS has been presented. Based on ANSYS Workbench, a three-dimensional finite element model for the structure has been created and employed in the analysis. One and three-directional components of the time histories for ground accelerations have been employed to compute the dynamic response of the structure. The dynamic characteristics, including the time histories for the relative displacement, velocity, absolute acceleration and von Mises stress distribution of the nuclear island structure were obtained for various earthquakes, including Japanese 1995 Kobe earthquake, American 1940 El Centro earthquake and Vietnamese 2001 Dien Bien earthquake. The obtained numerical results of the present work reveal that the dynamic response of the structure obtained from one-directional ATHs is different from that three-directional components of ATHs, and the dynamic characteristics of the structure obtained from the unidirectional ATHs are slightly underestimated. The safety of the nuclear island under in Dien Bien earthquake is not much concerned compares to that in El Centro and Kobe earthquakes. It should be noted that the nonlinearities which are often encountered when the structure subjected to strong earthquakes, and the soil-structure interaction have not been considered in the present work. More efforts should be made to take these factors into consideration in the seismic analysis of structures at nuclear power plants.

\section{REFERENCES}

[1] R. D. Campbell, G. S. Hardy, M.K. Ravindra, J. J. Johnson and A. J. Hoy, "Seismic re-evaluation of nuclear facilities worldwide: overview and status", Nucl. Eng. Des., vol. 182, no. 1, pp. 17-34, 1998.

[2] M. Manjuprasad, S. Gopalakrishnan, and T.V.S.R. Appa Rao, "Non-linear dynamic response of a reinforced concrete secondary containment shell subjected to seismic load", Eng. Struct., vol. 23, no.5, pp. 397-406, 2001.

[3] S. Tinic and R. Orr, "Finite element modeling of AP1000 nuclear island", T. 17 Int. Conf. Struct. Mech. Reactor Tech., Prague, Paper \#H05-4, 2003.

[4] L. Tunon-Sanjur, R.S. Orr, S. Tinic, and D.P. Ruiz, "Finite element modeling of the AP1000 nuclear island for seismic analyses at generic soil and rock sites", Nucl. Eng. Des., vol. 237, no. 12-13, pp. 1474-1485, 2007.

[5] N. Nakamura, "Seismic response analysis of deeply embedded nuclear reactor buildings considering frequency-dependent soil impedance in time domain", Nucl. Eng. Des., vol. 238, no. 7, pp. 1845-1854, 2008.

[6] N. Nakamura, S. Akitab, T. Suzuki, M. Kobab, S. Nakamura, and T. Nakano, "Study of ultimate seismic response and fragility evaluation of nuclear power building using nonlinear three-dimensional finite element model", Nucl. Eng. Des., vol. 240, no. 1, pp. 166-180, 2010.

[7] F. Perotti, M. Domaneschi, and S. De Grandis, "The numerical computation of seismic fragility of base-isolated Nuclear Power Plants buildings", Nucl. Eng. Des., vol. 262, pp. 189-200, 2013.

[8] Y. Huang, A.S. Whittaker, M.C. Constantinou, and S. Malushte, "Seismic demand on secondary system in basedisolated nuclear power plants", Earthq. Eng. Struct. Dyn., vol. 36, no. 12, pp. 1741-1761, 2007.

[9] C. Zhao and J. Chen, "Numerical simulation and investigation of the base isolated NPPC building under three-directional seismic loading", Nucl. Eng. Des., vol. 265, pp. 484-496, 2013

[10] I. Chen, C. Zhao, Q. Xu, and C. Yuan, "Seismic analysis and evaluation of the base isolation system in AP1000 NI under SSE loading", Nucl. Eng. Des., vol. 278, pp. 117133, 2014.

[11] I . Politopouos, I. Sergis, and F. Wang, "Floor response spectra of a partially embedded seismically isolated nuclear plant", Soil Dyn. Earthq. Eng., vol. 78, pp. 213217, 2015

[12] C.-H. Zhai, Z. Zheng, S. Li, and L.-L. Xie, "Seismic analyses of a RCC building under mainshock-aftershock seismic sequences", Soil Dyn. Earthq. Eng., vol. 74, pp. 46-55, 2015.

[13] R. Lo Frano and G. Forasassi, "Preliminary evaluation of seismic isolation effects in a Generation IV reactor", Energy, vol. 36, pp. 2278-2284, 2011.

[14] C. Zhao and J. Chen, "Dynamic characteristics of AP1000 shield building for various water levels and air intakes considering fluid-structure interaction", Prog. Nucl.r Energ., vol. 70, pp. 176-187, 2014.

[15] C. Zhao, J. Chen, and Q. Xu, Dynamic analysis of AP1000 shield building for various elevations and shapes of air intakes considering FSI effects subjected to seismic loading, Prog. Nucl. Energ., vol. 74, pp. 44-52, 2014.

[16] Q. Xu, J. Chen, C. Zhang, J. Li, and C. Zhao, "Dynamic analysis of AP1000 shield building considering fluid and structure interaction effects”, Nucl. Eng. Tech., vol. 48, no. 1, pp. 246-258, 2016.

[17] Inc. A., ANSYS Release 15.0 (Canonsburg, PA, USA, 2013).

[18] T. K. Datta, Seismic Analysis of Structures, Pte Ltd., Singapore: John Wiley \& Sons, 2010, pp. 99-151.

[19] R. D. Cook, D. S. Malkus, and M. E. Plesha, Concepts and applications of finite element analysis, $3^{\text {rd }}$ ed., John Wiley \& Sons, New York, USA: 1989, pp. 367-417.

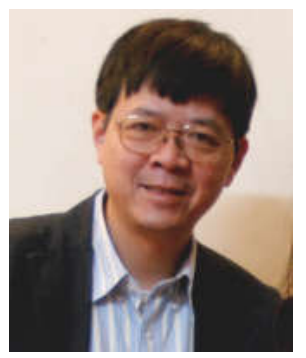

Nguyen Dinh Kien received the M.S. degree in composite materials from Nihon University, Japan and the $\mathrm{Ph} . \mathrm{D}$. degree in solid mechanics from Vietnam Academy of Science and Technology. $\mathrm{He}$ is currently a research associate at Institute of Mechanics, Vietnam Academy of Science and Technology. His main interest is finite element modeling of solids and structures. 


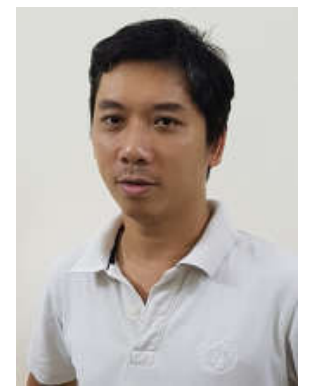

Vu Lam Dong received both the M.S. and $\mathrm{Ph}$. D. degrees in engineering mechanics from Vietnam Academy of Science and Technology. He currently works at Institute of Mechanics, VAST. He is working on bound evaluation of effective moduli of multi-phase composites and the finite element modeling of structures.

\title{
Phân tích địa chấn công trình đảo hạt nhân AP1000 sử dụng phần mềm phần tử hữu hạn ANSYS
}

\author{
Nguyễn Đình Kiên, Vũ Lâm Đông \\ Viện Cơ học, VAST, 18 Hoàng Quốc Việt, Hà Nội
}

Tóm tắt- Bài báo trình bày phương pháp phân tích địa chấn công trình đảo hạt nhân của nhà máy điện nguyên tử AP1000 trên cơ sở sử dụng phần mềm phần tử hữu hạn thương mại ANSYS. Mô hình phần tử hữu hạn 3 chiều cho công trình được khởi tạo bằng ANSYS Workbench và sử dụng trong phân tích. Đáp ứng động lực học của công trình với phổ gia tốc nền theo một và ba phương được quan tâm nghiên cứu. Mối quan hệ giữa chuyển vị, vận tốc tương đối và gia tốc tuyệt đối với thời gian được tính toán và thu nhận cho một số trận động đất khác nhau, kể cả El Centro ở Mỹ, Kobe ở Nhật Bản và Điện Biên ở Việt Nam. Kết quả số chỉ ra rằng các đặc trưng động lực học của công trình nhận được trên cơ sở gia tốc nền theo một và ba phương là khác nhau và gia tốc nền theo ba phương cần được sử dụng trong phân tích. Kết quả cũng cho thấy cống trình nhà máy điện hạt nhân dưới tác động của động đất Điện biên an toàn hơn khi chịu tác động của động đất El Centro và động đất Kobe. Sự phân bố của ứng suất von Mises ứng tại thời điểm chuyển dịch ở đỉnh công trình đạt giá trị lớn nhất cũng được khảo sát và nhấn mạnh.

Tù khóa-AP1000, đảo hạt nhân, phân tích địa chấn, mô hình phân tử hữu hạn, đáp ứng động lực học, ANSYS. 